\title{
Caracterização geológica do prospecto de óxido de ferro-cobre-ouro (IOCG) Aurora, Ceará, Brasil
}

\author{
Sérgio Roberto Bacelar Huhn ${ }^{1,3}$, Ana Paula Justo ${ }^{2}$, Carlos Roberto de Souza Filho ${ }^{3}$ \& \\ Lena Virgínia Soares Monteiro ${ }^{3}$
}

\begin{abstract}
Resumo O Prospecto Aurora localiza-se na região nordeste do Brasil (Estado do Ceará), na porção central da Província Borborema, no Domínio da Zona Transversal e possui idade meso a neoproterozoica, ao longo do Lineamento Patos. As ocorrências de cobre de Aurora são hospedadas por rochas metavulcano-sedimentares do Grupo Cachoeirinha. Intensos processos de cisalhamento e brechação hidrotermal estão associados à mineralização de cobre. Cloritização e albitização, sobrepostos por processos hidrotermais tardios, representados por alteração potássica com feldspato potássico e formação de óxidos de ferro (hematita), estão relacionados aos processos mineralizantes. As zonas mineralizadas são representadas por veios e zonas com sulfetos disseminados. A paragênese de minério é constituída predominantemente por calcopirita, calcocita, pirita e bornita subordinada; com malaquita e rara azurita compondo os termos oxidados. Os controles estruturais associados a zonas de cisalhamentos, a intensa alteração hidrotermal e o estilo de mineralização permitem classificar o Prospecto Aurora como semelhante aos depósitos da classe de óxido de ferro-cobre-ouro (iron oxide-copper-gold deposits ou IOCG) de idade brasiliana ou pós-brasiliana.
\end{abstract}

Palavras- chave: Prospecto Aurora, hidrotermal, calcopirita, hematita, IOCG, Província Borborema.

\begin{abstract}
Geological characterization of the Aurora iron oxide-copper-gold (IOCG) prospect, Ceará, Brazil. The Aurora copper occurrence is situated in the northeastern region of Brazil (Ceará State), within the Borborema Province and the Meso-Neoproterozoic mobile belt of the Transversal Zone Domain, along the Patos Shear Zone. The host rocks are composed mainly of metavolcanosedimentary units of the Cachoeirinha Group. Intense shearing and brecciation are related to hydrothermal processes and copper mineralization at the Aurora Prospect. Choritization and albitization superposed by later K-feldspar and hematite hydrothermal alteration are related with copper mineralization. The ore zones consist of veins and disseminated sulfides. The ore paragenesis comprises mainly chalcopyrite, chalcocite and pyrite. The structural control related to shear zone, the intense hydrothermal alteration and the style of mineralization indicate that the Aurora copper occurrence represents a Neoproterozoic to Paleozoic IOCG type of mineralization.
\end{abstract}

Keywords: Aurora Prospect, copper, hydrothermal, chalcopyrite, hematite, breccia, IOCG, Borborema Province.

INTRODUÇÃ̃O O Prospecto Aurora situa-se na Província Borborema, no sudeste do Estado do Ceará, em uma região na qual o interesse econômico para cobre tem sido demonstrado desde os anos 30 . Trabalhos sistemáticos de exploração mineral foram realizados no Prospecto Aurora pela CPRM em 1969. Mais recentemente, em meados dos anos 2000, a INCO Brasil e, posteriormente, a VALE, em 2005, desenvolveram pesquisa mineral na região.

A potencialidade de ocorrência de depósitos do tipo IOCG (iron oxide-copper-gold deposits) no contexto da Província Borborema é enfatizada pelos trabalhos realizados por Maas et al. (2003) e Machado (2006) na Faixa/Terreno Orós Jaguaribe. Esses trabalhos relacionam a ocorrência de depósitos de cobre associados a brechas quartzo-hematíticas existentes na região limitada pelas cidades de Mandacaru, São Julião, Fronteiras e Pio IX (PI) e Campos Sales (CE) à importante classe dos depósitos IOCG identificados no Brasil, notoriamente na região de Carajás (Huhn \& Nascimento 1997, Xavier et al. 2008, Monteiro et al. 2008, Grainger et al. 2008, Groves et al. 2010).

A caracterização geológica do Prospecto Aurora e a comparação de seus atributos com aqueles típicos de depósitos IOCG podem expandir o potencial metalogenético para a região, justificando esse estudo.

\section{CONTEXTO GEOLÓGICO REGIONAL A} Província Borborema (Fig. 1) é caracterizada por expressivo plutonismo granitoide, importantes zonas de cisalhamento e evolução por colagem de blocos crustais tectono-estratigráficos do embasamento

1 - Departamento de Desenvolvimento de Projetos Minerais, Gerência Geral de Exploração, VALE S/A, Belo Horizonte (MG), Brasil.

E-mail: sergio.bacelar@vale.com.br

2 - Companhia de Pesquisa de Recursos Minerais - CPRM, Residência de Fortaleza, Fortaleza (CE), Brasil. Email: apjusto@fo.cprm.gov.br

3 - Instituto de Geociências, Universidade Estadual de Campinas, Campinas (SP), Brasil. E-mail: beto@ige.unicamp.br,

lena@ige.unicamp.br 
gnáissico-migmatítico Arqueano a Paleoproterozoico (Maciços Medianos) e de unidades supracrustais representadas por rochas metassedimentares e metavulcânicas proterozoicas (Faixas Dobradas ou Faixas de Supracrustais) (Brito Neves 1975, 1983, Almeida et al. 1976, Santos \& Brito Neves 1984, Santos et al. 1984).

Os estudos de Jardim de Sá et al. (1992) e Jardim de Sá (1994) evidenciam a existência de complexidades e heterogeneidades, que indicam que a Província Borborema inclui terrenos de evolução distinta justapostos por zonas de cisalhamento, com registros da deformação e do magmatismo relacionados à orogênese Brasiliana. Pela magnitude dos Lineamentos Pernambuco e Patos, Jardim de Sá (1994) retomou para a província o conceito de Zona Transversal (Fig. 1), que seria limitada por esses dois extensos lineamentos.

Santos (1996) introduziu o modelo de terrenos litoestatigráficos para a Província Borborema, postulando que esta foi formada pela aglutinação de grandes fragmentos de crosta, justapostos durante as orogêneses Cariris Velhos (início do Neoproterozoico) e Brasiliana (final do Neoproterozoico). Com base em características geológicas gerais, bem definidas espacialmente, a Província Borborema foi subdividida em três distintos domínios: setentrional, zona transversal e meridional (Santos et al. 1997, Brito Neves et al. 2000). Os expressivos lineamentos Patos, ao norte, e Pernambuco, ao sul, balizam o segmento central da província, e dão forma retangular a esta zona (Brito Neves et al. 2005).

Oliveira et al. (2000) e Oliveira (2008) contribuíram para a evolução da concepção de terrenos tectonoestratigráficos na Província Borborema a partir de interpretações de dados magnéticos e gravimétricos. Segundo Oliveira et al. (2000), independente dos modelos evolutivos adotados, a divisão da província em cinco grandes domínios tectônicos é consensual e inclui: 1) Domínio Médio Coreaú, 2) Domínio Ceará (ou Cearense), 3) Domínio Rio Grande do Norte, 4) Domínio da Zona Transversal ou Central e 5) Domínio Sul ou Externo.

De acordo com essa compartimentação tectônica da Província Borborema (Almeida et al. 1977, Jardim de Sá 1994), a região do Prospecto Aurora encontrase recortada pelo Lineamento Patos. Esse lineamento divide a Província Borborema em dois domínios distintos: o Domínio Rio Grande do Norte (DRN), ao norte, e o Domínio da Zona Transversal (DZT), ao sul (Fig. 1). Segundo Van Schmus et al. (1995) e Santos (1999), na área do Prospecto Aurora, o DRN é representado pelo Terreno Granjeiro (com expressiva ocorrência do embasamento Arqueano e Paleoproterozoico) e o DZT (setentrional) pelo Terreno Piancó-Alto Santa Brígida (com predominância de rochas meso e neoproterozoicas) (Fig. 1). As diferenças entre os domínios e terrenos incluem, sobretudo, as diversidades dos episódios de acresção, sedimentação, vulcanismo e plutonismo pré-brasilianos, uma vez que a deformação e o plutonismo granítico brasilianos afetaram todos os segmentos, domínios e terrenos.

De acordo com a concepção de Jardim de Sá (1994), relativa ao contexto geotectônico da província, o Complexo Uauá-Caicó inclui unidades supracrustais e foi originado pela sucessiva acresção de arcos magmáticos, que teriam gerado uma protocrosta siálica durante um evento orogênico $\left(D_{1}\right)$, informalmente referido como Paleotransamazônico (2,3 a 2,15 Ga). Nappes e dobras recumbentes representariam um evento contracional de grande penetratividade $\left(\mathrm{D}_{2}\right)$, desenvolvido em condições da fácies xisto-verde a anfibolito e com transporte para SSE. Suítes graníticas sin a tarditectônicas (G2) constituem uma feição marcante desse evento tectônico, atribuído a um processo colisional datado em 1,9 a 2,1 Ga eadmitido como Neotransamazônico.

A ocorrência de rochas supracrustais, com evidências de deformação tangencial de idades distintas (meso e paleoproterozoicas), separadas por zonas de cisalhamento (ZC) e associadas a feições geofísicas específicas, sugere que a Província Borborema é composta por vários terrenos alóctones. Esses terrenos foram aglutinados durante a Orogênese Brasiliana e, possivelmente, também durante um evento anterior de ca. 1,0 Ga. Em uma etapa final da evolução da Província Borborema, todo o bloco situado entre as suturas principais que margeiam os crátons foi submetido ao retrabalhamento transcorrente com extrusão lateral de blocos (Jardim de Sá 1994).

Jardim de Sá (1994), considerando a rede de cisalhamentos transcorrentes brasilianos, define que no DZT o movimento nas ZCs de trend NE a ENE é sinistral e sincrônico à movimentação dextral das ZCs E-W. Tal movimento foi interpretado como antitético e conjugado com a rotação dos blocos situados entre os Lineamentos Patos e Pernambuco, configurando um arranjo do tipo dominó (Fig. 2). O modelo dominó proposto é corroborado pelos dados estruturais relativos ao alojamento de alguns plútons brasilianos, uma vez que o modelo prevê a abertura de espaços e a formação de cunhas adequadas para entrada e alojamento de magmas e zonas mineralizadas associados com estruturas antitéticas em relação ao Lineamento Patos.

Na porção norte do Lineamento Patos, no DRN, o Terreno Granjeiro inclui rochas metassedimentares e metavulcano-sedimentares incluídas no Complexo Uauá-Caicó, do Mesoproterozoico, e rochas do embasamento, constituído por ortognaisses tonalíticos com presença de rochas supracrustais de idade paleoproterozoica (Fig. 3). A idade mínima admitida para o Terreno Granjeiro foi estabelecida pelo método U-Pb em zircão de $2541 \pm 11$ Ma determinada em um ortognaisse tonalítico intrusivo neste terreno (Santos 1999, Ferreira \& Santos 2000).

Ao sul do Lineamento Patos, como representante do Domínio da Zona Transversal (Fig. 1), o Terreno ou Faixa Piancó-Alto Brígida é representado pelo Grupo Cachoeirinha (Barbosa 1970), composto dominantemente por rochas metassedimentares psamíticas e pelíticas e, subordinadamente, por rocha metamáficaintermediária, que contém restos de uma unidade metavulcano-sedimentar pelítico-química-exalativa.

O Grupo Cachoeirinha, subdividido em duas formações, Serra do Olho d'Água e Santana dos Garrotes, 


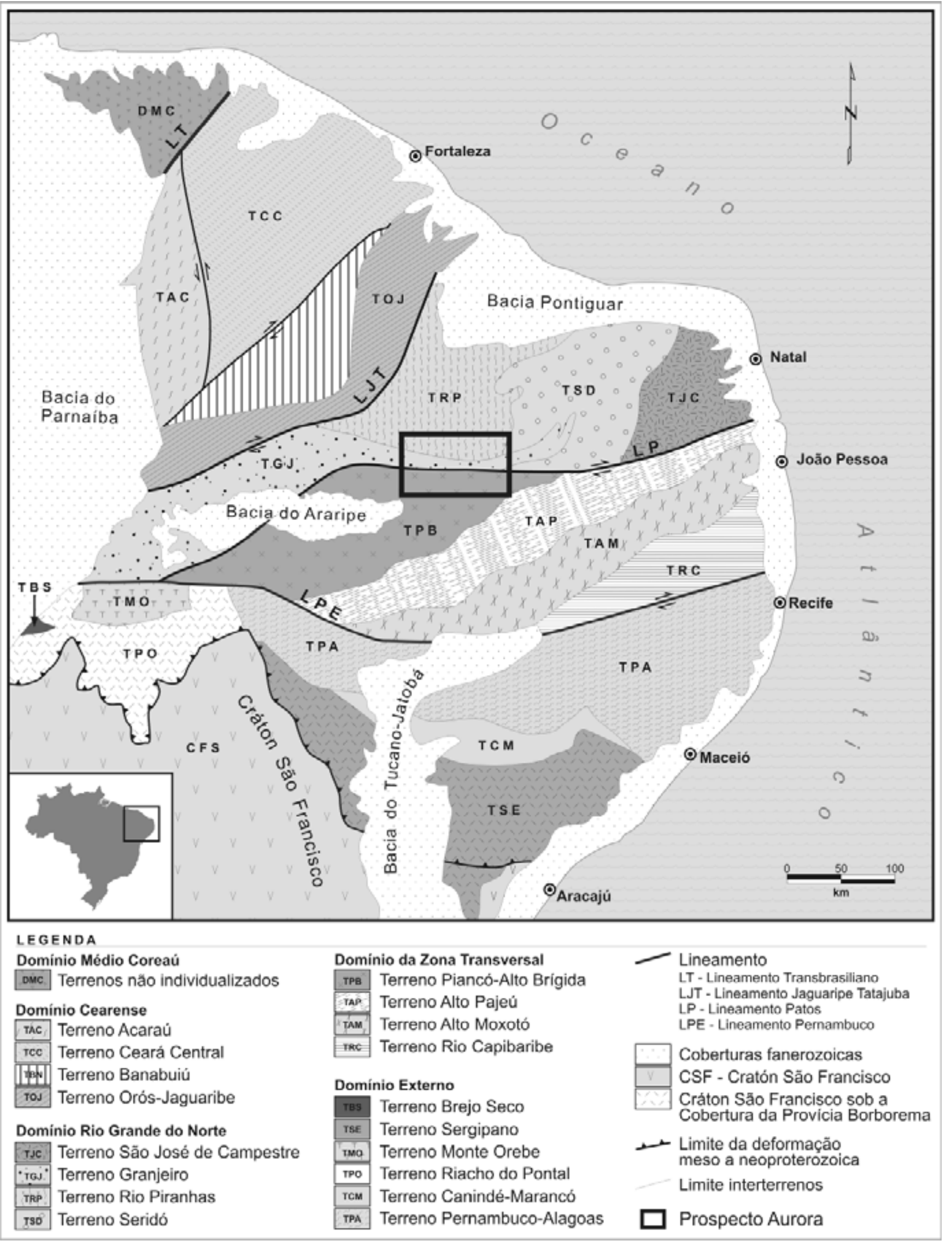

Figura 1 - Compartimentação da Província Borborema em domínios e terrenos tectono-estratigráficos, segundo Gomes (1998). 


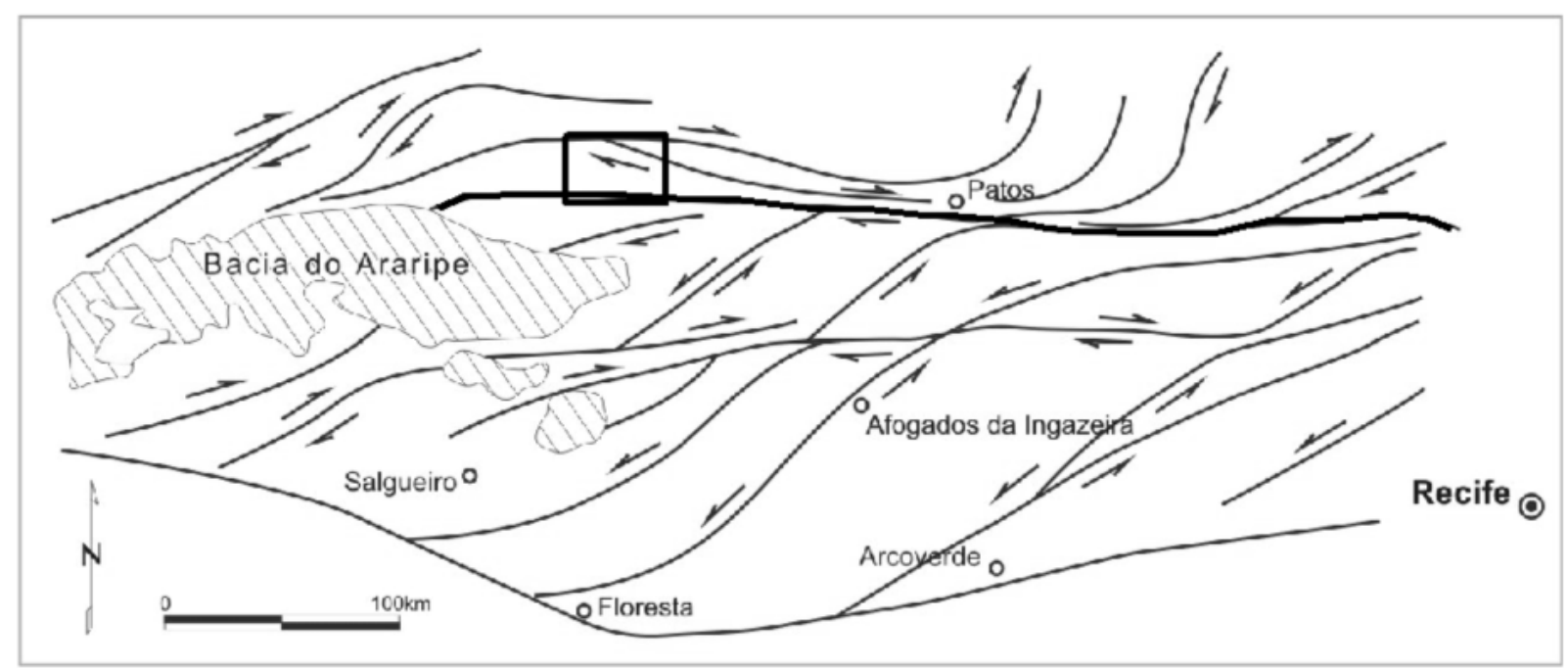

Figura 2 - Modelo integrado do conjugado de zonas de cisalhamento EW dextrais e NE sinistrais no Dominio da Zona Transversal (Jardim de Sá 1994). Em detalhe, a localização do Prospecto Aurora.

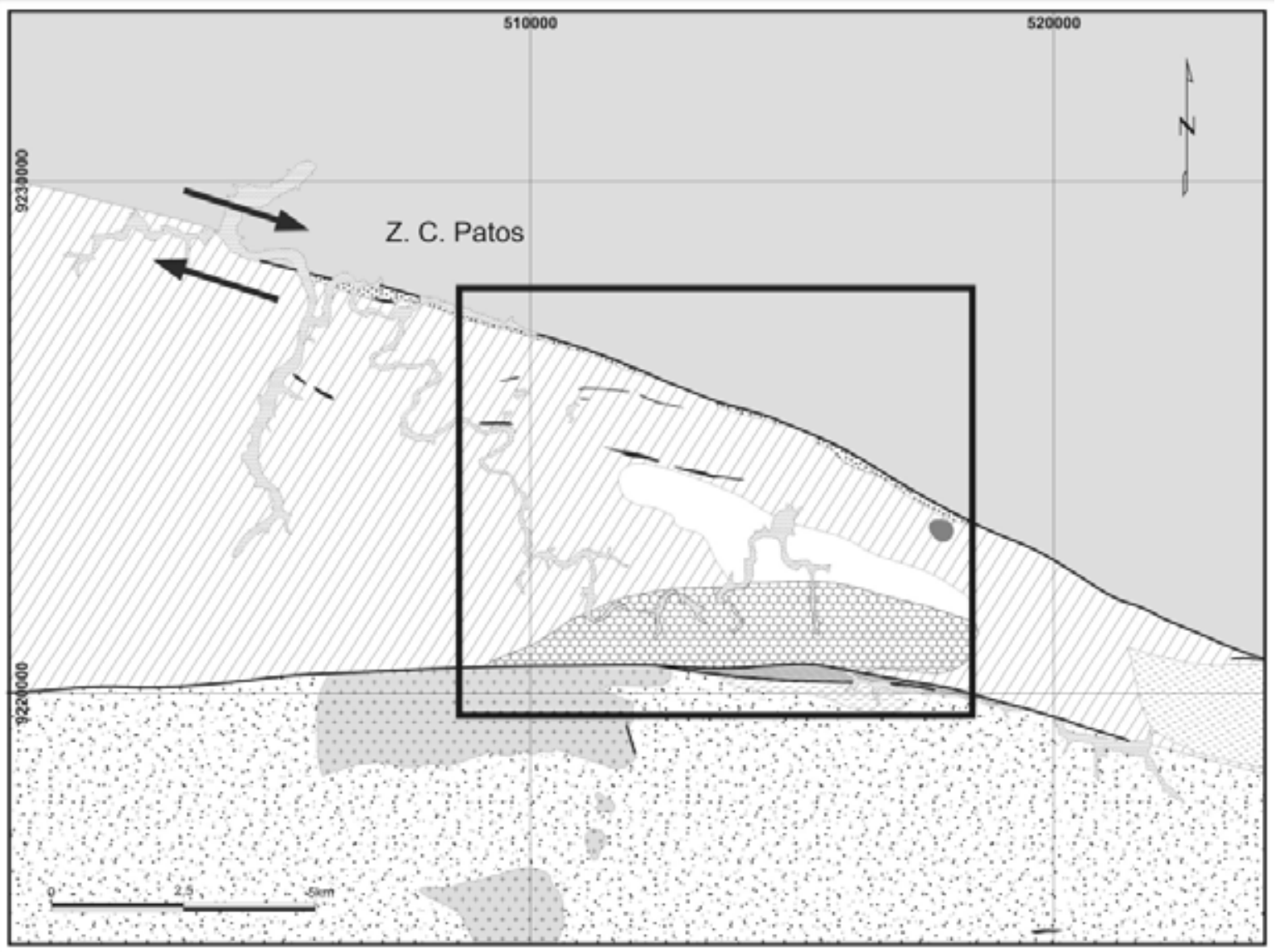

LEGENDA

Reita Brecha cataclástica (quartzo-feldspato-albitasericita-clorita) em matriz silico-hematitica

Depósitos quaternários

Brecha hidrotermal quartzo-feldspática-hematitica (traços de pirita>malaquita>calcopirita>azurita)

Zona fortemente albitizada

Quartzo-feldspato-muscovita-biotita-granada xistos;

Biotita-anfibólio gnaisses; frequentemente milonitizados

Quartzo-albita-clorita-sericita xisto

Xistos Metassedimentares
Granitoides de composição granodioritica

Sedimentos arcoseanos

Zonas de intensa silicificaçăo

Granada xistos recortado por veios pegmatoides

Xistos recortados por veios pegmatoides:

localmente milonitizados

- Falha

Prospecto Aurora

Figura 3 - Contexto geológico regional do Prospecto de cobre Aurora (modificado de Justo et al. 2008). 
compreende rochas cujos protólitos foram depositados em sistema turbidítico (Silva Filho et al. 1985, Campos Neto et al. 1994, Bittar 1998, Ferreira \& Santos 2000). Trata-se de uma sequência do tipo flysch, de idade neoproterozoica, cujos cristais de zircão detríticos foram datados em ca. $640 \mathrm{Ma}$ (Ferreira \& Santos 2000). O ambiente tectônico do Grupo Cachoeirinha tem sido considerado como relacionado à bacia de retroarco associada ao desenvolvimento de arco vulcânico neoproterozoico (Campos Neto et al. 1994, Kozuch et al. 1997, Gomes 1998, Bittar 1998, Ferreira \& Santos 2000).

A Formação Serra do Olho d'Água (Bittar 1998), basal e descontínua longitudinalmente, apresenta espessura aparente próxima dos $1.000 \mathrm{~m}$ e é composta por conglomerados polimíticos com matriz arenosa e areno-argilosa e clastos, até decimétricos, representando a provável fácies proximal de um sistema turbidítico mais amplo.

A porção superior da Formação Santana dos Garrotes (Bittar 1998) é dominante em extensão e magnitude. Caracteriza-se por pacotes turbidíticos areno-argilosos com algumas intercalações de metagrauvacas e metassedimentos químicos ferríferos (metamorfisados em baixo grau), com esparsas intercalações de rochas metavulcânicas básicas, intermediárias e ácidas, provavelmente de ambiente marinho.

Rochas sedimentares da Bacia de Iara, de idade eocambriana, ocorrem em um pequeno gráben balizado pelo Lineamento Patos. Estas rochas são compostas por conglomerados polimíticos, arenitos arcoseanos e folhelhos diversos (Barbosa 1970). Na área estudada (Fig. 3), estão representadas por sedimentos arcoseanos, situados na porção leste da área. A granulometria dos litotipos é variada, e ocorrem gradações de argilitos e siltitos para arenitos e arenitos conglomeráticos, chegando, próximo ao contato com embasamento, a conglomerados grossos polimíticos e brechas sedimentares. Ocorrências de malaquita foram registradas nesta unidade relacionadas às bordas do gráben e associadas a brechas sílico-hematíticas (CPRM 1982).

Historicamente, as ocorrências de cobre de Aurora foram posicionadas na borda norte de um gráben intracontinental neoproterozoico, denominado Bloco Cuncas-Barro (Gráben de Aurora), que foi preenchido pelos sedimentos siliciclásticos do Grupo Cachoeirinha (Barbosa 1970). Na porção centro sul as unidades neoproterozoicas do Gráben de Aurora são recobertas pelos sedimentos Paleozoicos e Mesozoicos, incluídos na Formação Cariri ou Mauriti, e nos grupos Missão Velha (ou Grupo Vale do Cariri) e Araripe (Ferreira \& Santos 2000).

\section{CONTEXTO GEOLÓGICO DO PROSPECTO} AURORA O Prospecto Aurora situa-se ao longo do Lineamento Patos, mais precisamente a sul da sua inflexão WNW-ESE, onde predomina uma faixa cataclástica de expressão regional. O Lineamento Patos corresponde à principal estrutura tectônica da área e marca o contato de alto ângulo entre as rochas supracrustais meso-neoproterozoicas do Grupo Cachoeirinha com seu embasamento Arqueano/Paleoproterozoico, representado pelo Terreno Granjeiro (Parente \& Arthaud 1995). Brechas tectônicas estão alojadas neste corredor tectônico (Fig. 4).

A mineralização de cobre ocorre em brechas hidrotermais presentes tanto no embasamento gnáissico-migmatítico, como na sequência metavulcano-sedimentar, meso a neoproterozoica da Formação Santana dos Garrotes (Grupo Cachoeirinha).

A intensa milonitização, frequentemente observada nas rochas ferruginosas, levou a CPRM (1982) a interpretá-las como formações ferríferas. No entanto, os estudos realizados indicam que, pelo menos em sua maior parte, tais rochas ferruginosas (incluindo àquelas maciças, bandadas e/ou foliadas e brechas hematíticas), correspondem aos hidrotermalitos gerados pelos processos mineralizantes responsáveis pelas ocorrências de cobre registradas no Prospecto Aurora.

Justo et al. (2008) indicam que as zonas cloritizadas observadas no Prospecto Aurora formaram-se a partir da alteração hidrotermal de rochas metavulcânicas, representantes de um vulcanismo "espelito-queratófiro", com predomínio de rochas metaqueratófiras e metapiroclásticas em relação a pequenos corpos de riolitos, traquitos, riodacitos e felsitos brechados. Intercalados aos litotipos acima, foram descritas brechas hematíticas compostas por fragmentos de metacherts, metaqueratófiros e massas quartzo-feldspáticas cimentados por material rico em sílica e hematita.

\section{Caracterização das principais unidades geológicas} do Prospecto Aurora O mapeamento geológico realizado no Prospecto Aurora resultou em mapa na escala 1:5.000 com as zonas de ocorrência de brechas sílico-hematíticas individualizadas das demais unidades litológicas presentes na área. As zonas mineralizadas mais significativas estão associadas aos hidrotermalitos, brechas sílico-hematíticas e cataclásticas. As características das principais unidades geológicas são apresentadas a seguir.

\section{BIOTITA-GNAISSES E ANFIBÓLIO-GNAISSES} (TERRENO GRANJEIRO) O embasamento gnáissico-migmatítico do Terreno Granjeiro ocorre na porção norte do prospecto. As rochas gnáissicas apresentam composição granodiorítica, granulação equigranular média e bandamento gnáissico, definido por bandas com textura granoblástica, ricas em quartzo, plagioclásio e piroxênio/anfibólio, alternadas a bandas com textura lepidoblástica ricas em biotita. Apresentam feições migmatíticas e dobras em bainha localizadas. Ortognaisses tonalíticos também ocorrem na área e são representados por biotita-hornblenda gnaisses de cor cinza e granulação média. A associação mineral é representada por oligoclásio-andesina, hornblenda, biotita, quartzo e, subordinadamente, por microclínio, epidoto e ilmenita. A textura milonítica mascara texturas primitivas reliquiares. 


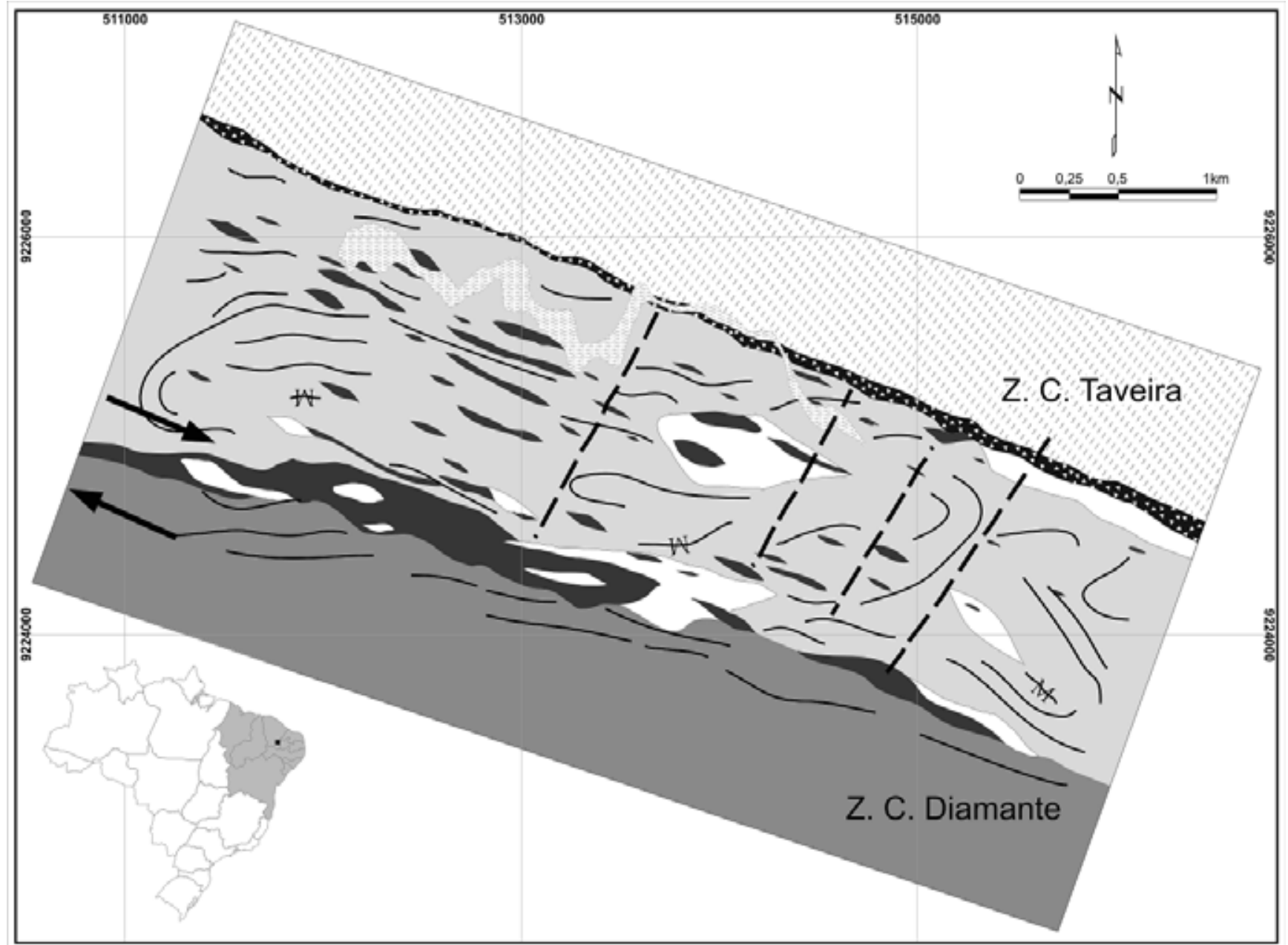

LEGENDA

Aluvião

Biotita-gnaisses e/ou anfibólio-gnaisses

27.8 Brecha cataclástica c/ quartzo-feldspato-albita-Sericita-clorita em matriz sillico-hematítica c/ magnetita (traços de malaquita>azurita>calcopirita>calcocita>pitch-limonite)

Brecha hidrotermal quartzo-feldspática-hematitica

(traços de malaquita>azurita>calcopirita>calcocita)

Hidrotermalito a quartzo e albita

Quartzo-albita-clorita-sericita xisto

Quartzo-feldspato-muscovita-biotita-granada xisto

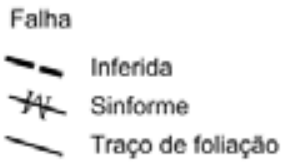

Figura 4 - Contexto geológico local do Prospecto Aurora.

Intensos processos hidrotermais afetaram os gnaisses ao longo das zonas de cisalhamento. Isso resultou em forte potassificação, com formação de feldspato potássico, que predomina em relação ao plagioclásio, associado a quartzo, hematita, magnetita, sericita e minerais do grupo do epidoto (pistacita e allanita), além de sulfetos. Zonas com enriquecimento em albita, biotita e clorita hidrotermais são também reconhecidas.

A faixa mais fortemente hidrotermalizada é caracterizada pela presença de bolsões boudinados de quartzo, feldspato potássico e actinolita, comumente cloritizada, com epidoto e hematita associados. Nesta rocha ocorre um amplo predomínio de feldspato potássico pertítico sobre o plagioclásio. Os cristais de feldspato potássico são alongados e com extinção ondulante e aspecto turvo devido à presença de hematita finamente disseminada.

\section{SEQUENCIA METAVULCANO-SEDIMENTAR (GRU-}

PO CAHOEIRINHA) Na porção central da área de pesquisa afloram xistos formados a partir de protólitos vulcânicos com composição essencialmente dacítica, representantes da base da sequência metavulcano-sedimentar da Formação Santana dos Garrotes do Grupo Cachoeirinha (Campos Neto et al. 1994). Predominam feldspato-plagioclásio-sericita-clorita-quartzo xistos, com coloração cinza-esverdeada, quando frescos, e creme-amarelado, quando intemperizados. A foliação da rocha é definida pela orientação da clorita e sericita, com plagioclásio associado, que 
pode ocorrer parcialmente substituído por epidoto. A estrutura xistosa fina a subordinadamente filítica está localmente crenulada e suavemente dobrada, em geral com veios de quartzo centimétricos, ondulados, concordantes com a foliação. Como minerais acessórios, ocorrem magnetita e pirita idioblásticas, em geral associados com clorita e epidoto, que acompanham a foliação dobrada e, localmente, apresentam-se como cristais maiores que cortam a foliação.

Metatufitos com coloração cinza, granulação fina e composição mineralógica dominada por quartzo, feldspatos, sericita e clorita, possuem uma composição riodacítica. Em alguns litotipos, provavelmente subvulcânicos, a biotita pode estar presente. O plagioclásio predomina sobre o feldspato potássico, é turvo devido à intensa sericitização, ocorrendo na matriz e como porfiroclastos arredondados envoltos pela foliação da rocha. Da mesma forma que o plagioclásio, o quartzo ocorre tanto com granulação fina na matriz como porfiroclastos arredondados ou alongados. Nas rochas predominantes desta unidade, a clorita é o principal filossilicato da matriz, conferindo a xistosidade à rocha. Minerais do grupo do epidoto (pistacita e zoisita) são bastante comuns. Sericita, em geral como alteração de plagioclásio, e acessórios (titanita, apatita, zircão, leucoxênio e opacos), também foram identificados. As associações e paragêneses minerais das rochas metavulcânicas/vulcanoclásticas são típicas de condições condizentes com baixo grau metamórfico, em fácies xisto-verde. Sobrepondo por cavalgamento esta porção metavulcânica/ vulcanoclástica, ocorrem rochas metassedimentares, representadas por feldspato-biotita-muscovita-quartzo xistos com granada, em geral com colorações cinza (rocha fresca) e amarronzada (produtos intemperizados). A estrutura xistosa fina a média apresenta dobras apertadas. É frequente a presença de veios pegmatíticos constituídos por quartzo, muscovita e turmalina preta, em geral, acompanhando a foliação. Cortando estas rochas ocorrem veios de quartzo, às vezes poligonizado, e zonas constituídas por quartzo e albita.

TECTONITOS: BRECHAS, CATACLASITOS E ULTRACATACLASITOS A região do contato entre o embasamento (Complexo Uauá-Caicó) e as supracrustais (Grupo Cachoeirinha) é marcada pela Zona de Cisalhamento Transcorrente Taveira (Fig. 4), que afetou ambas as unidades. Nesta região são observadas estreitas faixas de ultracataclasitos, cataclasitos, brechas tectono-hidrotermais, além de faixas subordinadas de xistos metavulcano/vulcanoclásticos mais preservadas da deformação.

As rochas cataclásticas, de composição quartzo-feldspática, são caracterizadas por porfiroclastos de quartzo com extinção ondulante e formação de subgrãos e matriz constituída por cristais microgranulares de quartzo associados com biotita e óxidos de ferro (magnetita e/ou hematita).

Em faixas mais deformadas, já no domínio dos xistos metavulcânicos, ocorrem ultracataclasitos com trituramento dos grãos de quartzo e acunhamento das lamelas de maclas dos cristais de plagioclásio. O acentuado turvamento do plagioclásio deve-se às minúsculas inclusões de óxido de ferro e à presença de múltiplas inclusões fluidas. De forma subordinada, o plagioclásio está leve a moderadamente sericitizado e eventualmente com clorita associada.

As brechas cataclásticas (tipo Taveira) caracterizam-se por fragmentos angulosos submilimétricos a centimétricos de agregados de quartzo, albita, clorita e sericita e fragmentos de rocha granolepidoblástica, constituída essencialmente por clorita, plagioclásio com quartzo subordinado. Os fragmentos ocorrem imersos em matriz granular fina de cor cinza-esverdeada com tons arroxeados devido à presença de hematita e magnetita subordinada. O quartzo tem extinção ondulante, ocorre como subgrãos e contém múltiplas inclusões fluidas. Estruturas do tipo boxworks, associadas a óxido de ferro e clorita, acompanham os opacos alterados. Em alguns locais observa-se trituramento acentuado dos grãos, acompanhado de vênulas e fraturas preenchidas por quartzo e clorita associados aos minerais opacos (incluindo hematita e rara calcopirita) $\mathrm{e}$, às vezes, malaquita.

Os tectonitos são recortados por veios e vênulas compostos por cristais de quartzo, plagioclásio e opacos associados. O plagioclásio presente nestas vênulas é mais límpido do que aqueles que compõem os tectonitos encaixantes, indicando sucessivas gerações.

Reativações de caráter rúptil dos sistemas de cisalhamento regionais deram origem às bacias fanerozoicas, especialmente durante o Paleozoico (Eocambriano (?)/Siluro-Devoniano até Permo-Carbonífero) e no Mesozoico, no período Juro-cretácico, condicionando as bacias sedimentares paleozoicas e cretáceas encontradas na região.

Os tectonitos observados na região leste da área em estudo, próximos à zona de cisalhamento Taveira (Fig. 4), afetam os arcóseos correlacionáveis aos sedimentos aflorantes na Bacia de Iara e evidenciam que o Lineamento Patos foi reativado por sistemas de falhamentos eocambrianos.

\section{BRECHAS QUARTZO-FELDSPÁTICAS-HEMATÍTI-}

$C A S$ As brechas de composição quartzo-feldspática-hematítica sustentam uma série de serrotes distribuídos por toda a região, sendo os litotipos predominantes no Serrote do Diamante. Tais brechas são conhecidas como dos tipos Diamante e Aurora, ocorrendo também associadas às brechas cataclásticas do tipo Taveira. Essas designações diferenciam principalmente o litotipo a partir do qual foram desenvolvidas as zonas de brechas sílico-feldspáticas-hematíticas. Essas zonas podem incluir xistos metavulcano-sedimentares meso a neoproterozoicos, gnaisses e migmatitos do embasamento arqueano e brechas cataclásticas no contato gnaisse-xistos (tipo Taveira), além de sedimentos arcoseanos de bacias eocambrianas.

As brechas quartzo-hematíticas são caracterizadas por trama tipo stockwork com intercalações locais de hematita maciça e compostas por fragmentos 
angulosos de quartzo e agregados quartzo-K-feldspáticos-albíticos, imersos em matriz sílico-hematítica fina. $\mathrm{Na}$ matriz ocorre pirita disseminada euédrica, submilimétrica a centrimétrica, além de rara calcopirita e malaquita. Vênulas e fraturas preenchidas por material sílico-hematítico recortam todo o conjunto, em geral, com malaquita subordinada.

Em testemunhos de sondagem (realizados pela Vale S.A.) observam-se vênulas com magnetita, aqui interpretadas como prováveis representantes hidrotermais distais das brechas quartzo-feldspáticas hematíticas supracitadas.

HIDROTERMALITO COM QUARTZO E ALBITA Hidrotermalitos ocorrem como diques, veios e bolsões cortando todas as unidades anteriormente descritas e os sedimentos arcoseanos da Bacia de Iara. São representados por rochas com predominância de quartzo e albita, com clorita subordinada, textura maciça e, em geral, coloração rósea-esbranquiçada devido à presença de hematita microcristalina, gradando para cinza quando mais silicosa e fina. Quando parcialmente intemperizada, a rocha adquire aspecto pulverulento e cor amarela-esbranquiçada. Localmente apresenta xistosidade incipiente.

O hidrotermalito, com quartzo e albita, e suas encaixantes imediatas, em geral são ricos em malaquita. Quando parcialmente preservado do intemperismo, podem ser identificados sulfetos (pirita, calcopirita, calcocita e bornita) e seus produtos de oxidação, tais como malaquita e azurita, além de material silicoso e de cor verde (crisoprásio?). São comuns stockworks hematíticos e o desenvolvimento de boxworks a partir dos sulfetos e da hematita. Veios de quartzo com granulação grossa, às vezes associados a opacos, cortam estas rochas.

MINERALIZAÇÃO DE COBRE As ocorrências de cobre conhecidas entre as zonas de cisalhamento transcorrentes Taveira e Diamante (Fig. 4) estão compreendidas em uma faixa com extensão superior a $150 \mathrm{~km}$ e largura média de $20 \mathrm{~km}$. Localmente, as zonas mineralizadas encontram-se dispostas de forma anastomosada ao longo de uma faixa com cerca de $30 \mathrm{~km}$ de extensão e largura entre 3 e $5 \mathrm{~km}$, entre essas ZCs.

O minério de cobre é hospedado pela unidade de topo da sequência metavulcano-sedimentar de baixo grau metamórfico da Formação Santana dos Garrotes, Grupo Cachoeirinha. De acordo com os trabalhos realizados pela CPRM (1982), as zonas mineralizadas ocorrem junto às "formações ferríferas brechadas e/ou milonitizadas" ou em suas proximidades, especialmente das formações ferríferas que se encontram intercaladas às rochas metavulcânicas com tendência andesíticas e riolíticas (metaqueratófiros). Tais rochas, significativamente modificadas por processos de alteração hidrotermal, representam hidrotermalitos que formam corpos alongados, concordantes às zonas de cisalhamento. Esses hidrotermalitos apresentam dimensões variáveis, com espessuras entre poucos centímetros até $20 \mathrm{~m}$, podendo estender-se lateralmente ao longo da foliação por mais de $3 \mathrm{~km}$.

A foliação regional (Fig. 4) é truncada em alto ângulo por zonas mineralizadas ressaltadas por brechas hematíticas e feldspáticas, as quais estão relacionadas aos sistemas de transcorrência e falhas oblíquas de alto ângulo. Com base nos trabalhos aqui executados, foram delimitadas duas zonas mineralizadas principais, orientadas segundo um trend $\mathrm{N} 80 \mathrm{~W}$, condicionadas pelo Lineamento Patos e, localmente, pelas zonas de cisalhamento transcorrentes de Taveira e Diamante. As mineralizações e brechas sílico-feldspáticas-hematíticas que ocorrem ao longo destas falhas apresentam mergulhos verticalizados ou de alto ângulo, em geral, para Sul. Em particular, a Zona de Cisalhamento Taveira (Fig. 4) na região recorta os sedimentos arcoseanos da bacia de Iara, que é retrabalhada e possui registro de remobilização de cobre em zonas brechadas (Justo et al. 2008).

A mineralização de cobre é composta predominatemente por calcopirita, calcocita e pirita e está associada às brechas sílico-hematíticas e hidrotermalitos quartzo-albíticos, cujas associações minerais são compostas por sílica amorfa, albita, hematita, com calcita e sericita.

ALTERAÇÃO HIDROTERMAL Os processos de alteração hidrotermal que acompanharam a deformação cisalhante na área do Prospecto Aurora podem ser agrupados e hierarquizados. Visando a detecção das associações minerais associadas à alteração hidrotermal, foi realizada a análise de agrupamento hierárquico para 16 variáveis utilizando o método aglomerativo e a regra de agrupamento de Ward. As 16 variáveis estudadas foram obtidas a partir da análise de testemunhos de sondagem, levando em consideração as diferentes tipologias de alteração hidrotermal observadas macroscopicamente e nos estudos petrográficos. O método aglomerativo considera, inicialmente, cada observação como um agrupamento separado e prossegue combinando-as até que todas as observações pertençam a um agrupamento (Ward 1963).

O resultado da análise de agrupamento hierárquico está representado nas figuras 5 e 6 . Para a distância de amalgamação de $0,6 \mathrm{~mm}$, observam-se 3 grupos de variáveis: (1) 3, 4, 5, 8, 9, 10,11, 12, 13, 15, 16; (2) 7 e 6 e; (3) 1, 2 e 14. Estes 3 conjuntos de agrupamento foram retirados a partir da análise de testemunhos de sondagem, apresentando diferentes tipologias de alteração hidrotermal identificados nos trabalhos exploratórios executados pela Vale S.A.

Com base nessa análise, 4 grupos principais de processos de alteração hidrotermal podem ser identificados, relacionados ao cisalhamento precoce (cloritização e albitização) e a eventos tardios (potassificação e hematitização):

1) Cloritização: é caracterizada pela presença de quartzo, clorita e albita. A pirita ocorre tardiamente ao 


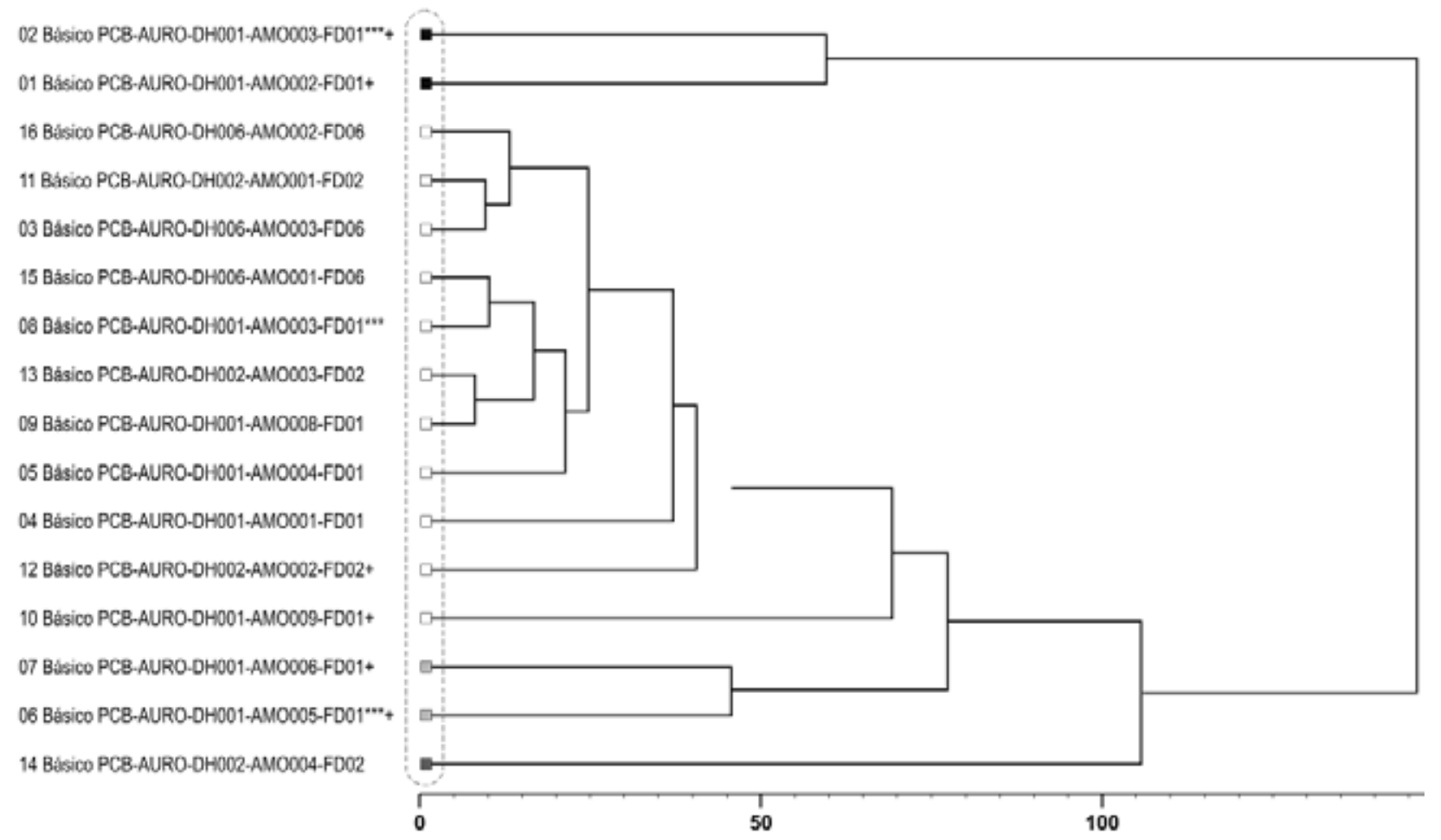

Figura 5 - Diagrama de agrupamento hierárquico calculado para os resultados analiticos de 16 variáveis, correspondentes aos tipos de zonas de alteração hidrotermal identificadas nos testemunhos de sondagem.

longo de zonas de fraturas. O desenvolvimento de foliação milonítica penetrativa a pouco incipiente acompanhou este processo hidrotermal;
2) Albitização: processo associado com a formação de clorita, albita, calcita e pirita, relacionada às zonas com milonitização mais intensa associada;

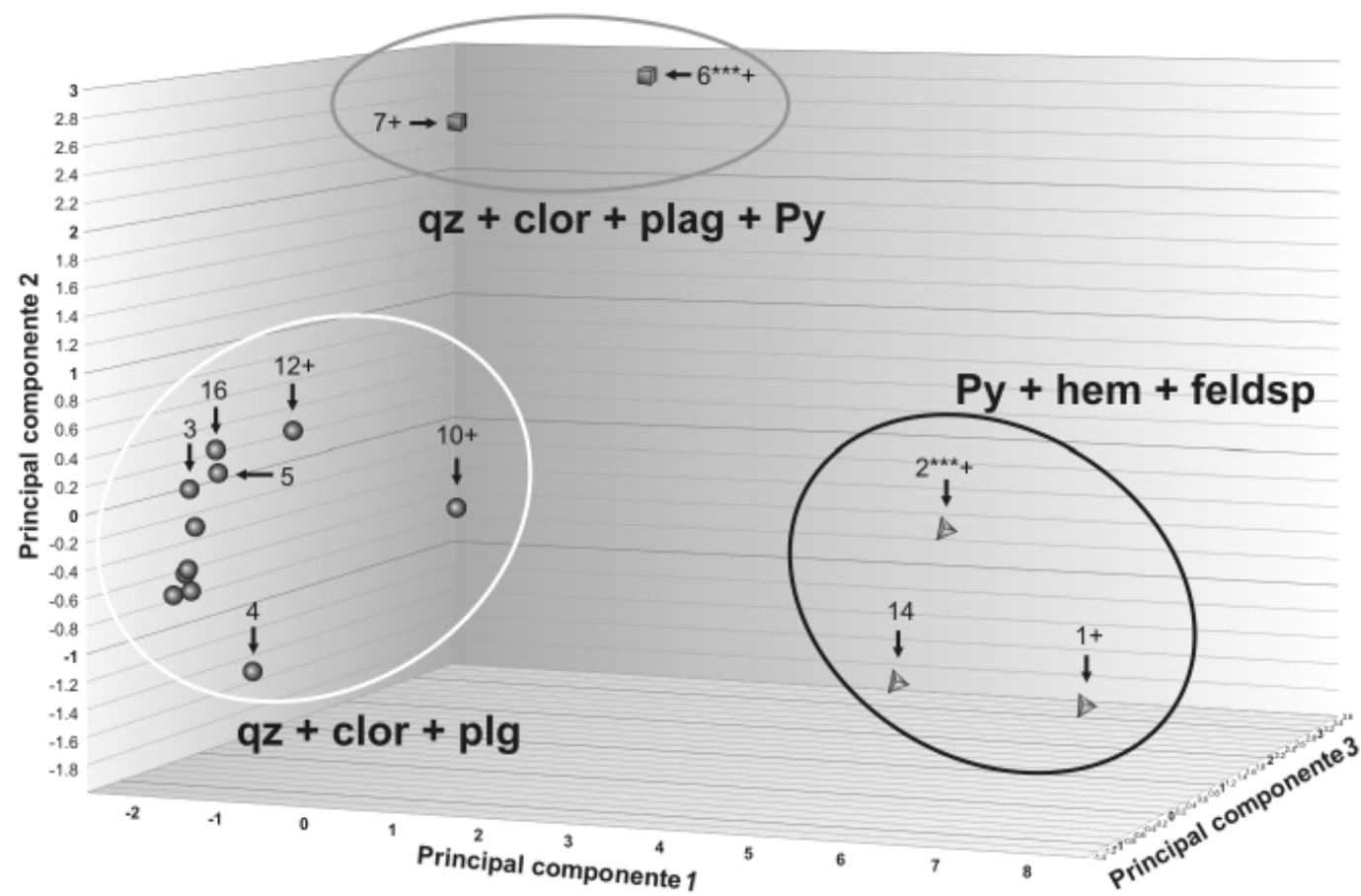

Figura 6 - Mineralogia relacionada aos 3 principais grupos de variáveis identificados: 1) quartzo + clorita + albita; 2) quartzo + clorita + albita + pirita; 3) feldspato potássico + pirita + hematita. 
3) Potassificação: é definida pela presença de feldspato potássico + hematita + albita + pirita \pm calcopirita associados à deformação cisalhante penetrativa com brechação relacionada;

4) Hematitização: é representada por veios e zonas brechadas quartzo-hematíticas.

Com base nesses dados foi possível mapear o principal zoneamento hidrotermal identificado no Prospecto Aurora (Fig. 7).

O sistema evolutivo do Lineamento Patos é entendido como uma zona de cisalhamento dúctil com milonitos associados, que foi superimposta por processos deformacionais dúcteis-rúpteis. Esses últimos seriam representados por zonas com predomínio de brechas e cataclasitos, onde foram alojadas as principais mineralizações de cobre do Prospecto Aurora.

DISCUSSÃO Os modelamentos descritivos e genéticos de depósitos minerais são importantes para a exploração mineral, uma vez que podem ser utilizados como uma ferramenta para a descoberta de novos jazimentos (Cox et al. 1986). No caso do Prospecto Aurora, a ocorrência de cobre identificada não pode ser classificada como uma jazida, uma vez que não apresenta reserva nem teor ou continuidade das zonas mineralizadas que a tornem econômica. No entanto, a compreensão dos processos e fatores que favoreceram a mineralização pode ser fundamental para a localização de depósitos minerais economicamente importantes vinculados ao mesmo sistema hidrotermal ou a outros semelhantes.

No Prospecto Aurora, a mineralização de cobre é composta por pirita (dominante) e calcopirita, que compõem mais de $90 \%$ dos sulfetos presentes nas zonas mineralizadas, acompanhados por calcocita, covelita, cuprita e bornita. Tais zonas mineralizadas associam-se aos hidrotermalitos quartzo-albíticos, que podem representar produtos finais de processos intensos de alteração inicial sódica, desenvolvida em condições dúcteis, seguidos por cloritização, potassificação e hematitização, representada por brechas sílico-hematíticas.

$\mathrm{O}$ fato das brechas sílico-hematíticas e hidrotermalitos quartzo-albíticos recortarem unidades de diferentes idades ao longo do Lineamento Patos e estruturas secundárias (zonas de cisalhamento transcorrentes Taveira e Diamante) mostra o caráter epigenético da mineralização de Aurora.

Embora a mineralização distribuída nas duas principais zonas de cisalhamento transcorrentes ocorra hospedada em corpos de brechas com características distintas, possivelmente os fluidos hidrotermais responsáveis pelo transporte das soluções cupríferas foram os

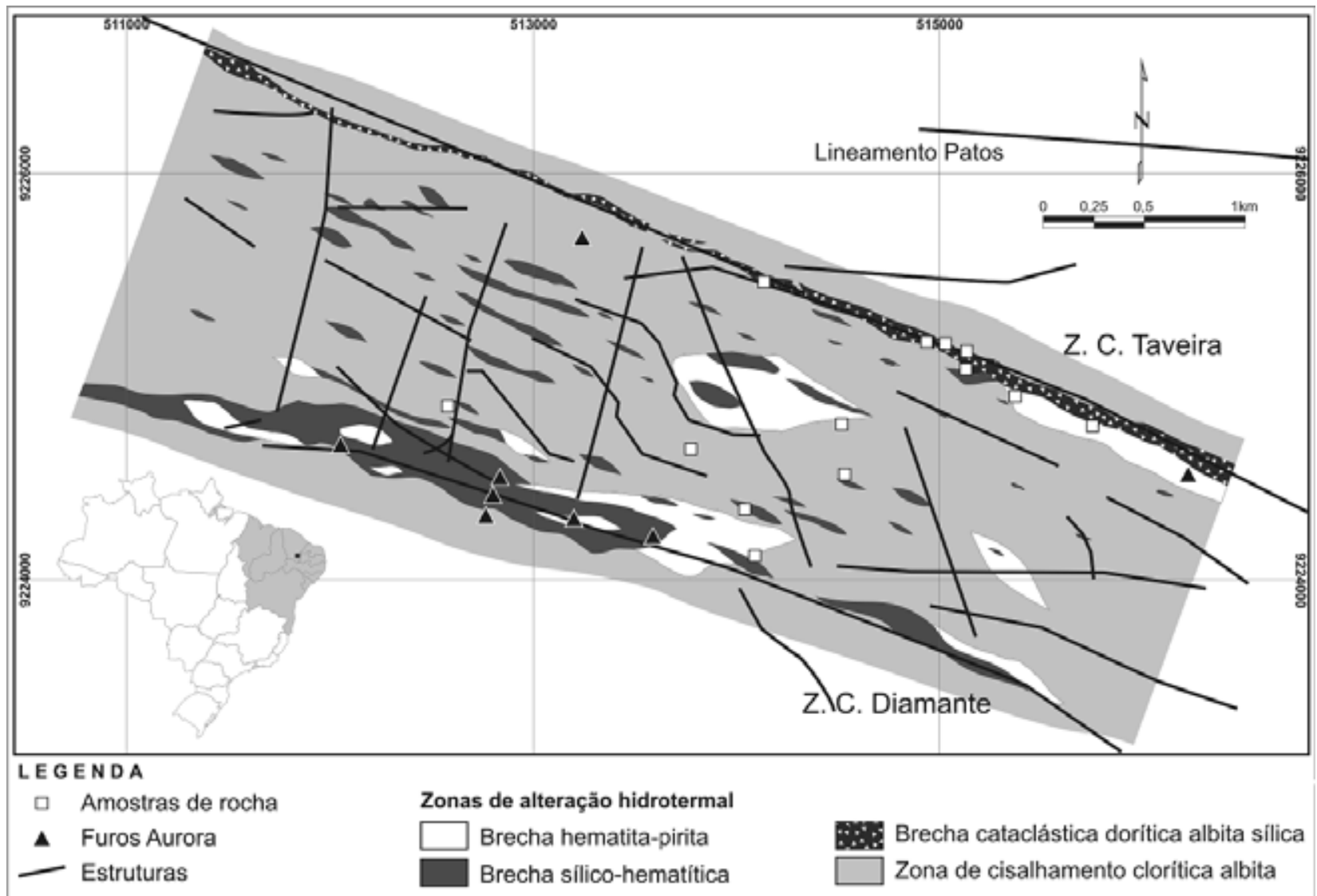

Figura 7 - Mapa de zoneamento de alteração hidrotermal do Prospecto Aurora, confeccionado a partir de testemunhos de sondagem e mapeamento geológico. 
mesmos. Interpreta-se que a zona de conduto responsável pela migração dos fluidos entre os dois principais sítios de mineralização apresenta direção NNE e está mais desenvolvida em níveis crustais mais rasos. Este arranjo geométrico de permeabilidade mais elevada é sugerido pelas marcantes venulações quartzo-albíticas de direção NNE presentes na área de estudo (Fig. 8).

A associação mineralógica das brechas mineralizadas indica que, possivelmente, os fluidos hidrotermais metalíferos foram oxidantes, como evidenciado pela presença de hematita. $O$ forte controle estrutural verificado no Prospecto Aurora, assim como a sequência de estágios de alteração, notadamente a predominância de alteração sódica em estágios iniciais e de alteração potássica mais tardia associada com a formação de óxidos de ferro, é semelhante àquelas tipicamente verificadas em depósitos IOCG (iron oxide-copper-gold deposits; Hitzman et al. 1992). A magnetita ocorre localmente como vênulas e pode representar a transição para as zonas distais.

Depósitos IOCG têm recebido considerável atenção exploratória, devido ao seu tamanho e teores relacionados. Estes depósitos mostram uma relação temporal e espacial com grandes batólitos (Pollard 2006) como no Cráton Eastern Gawler, Austrália (Olympic Dam, Prominent Hill), no Distrito Cloncurry, Austrália (Ernest Henry), na Província Mineral de Carajás, Brasil (Salobo, Cristalino, Sossego e Alemão) e no Coastal Batholith, norte do Chile (La Candelária e Manto Verde), segundo Williams et al. (2005) e Groves et al.
(2010). Porém, em escala de detalhe, não há uma íntima associação com uma intrusão em particular, como é conhecida, por exemplo, em depósitos de skarn e depósitos de cobre do tipo pórfiro.

Depósitos IOCG ocorrem em uma variedade de níveis crustais. Segundo o modelo de Pollard (2000), em níveis crustais profundos, fluidos ricos em $\mathrm{CO}_{2}$ separam-se dos magmas a elevada pressão com relação a sistemas pobres em $\mathrm{CO}_{2}$, favorecendo a partição de metais para a fase fluída, o que possibilitaria a concentração dos metais de origem magmática. Nesses níveis crustais profundos predominam zonas de cisalhamento dúctil, com depósitos hospedados em traps estruturais. Em níveis crustais mais rasos, os depósitos seriam hospedados em sistemas hidrotermais dominados por brechação hidrotermal. O zonamento da alteração hidrotermal caracteriza-se pela alteração hidrotermal sódico-(cálcico) em zonas mais profundas, evoluindo para zonas potássicas e ricas em carbonato em níveis crustais mais rasos.

No Prospecto de Aurora, os estágios iniciais de desenvolvimento do sistema hidrotermal representados pela alteração com albita associam-se às estruturas dúcteis, notadamente ao Lineamento Patos e às Zonas de Cisalhamento Transcorrentes Taveira e Diamante, enquanto o estágio de mineralização e formação de brechas sílico-hematíticas seriam tardios e relacionados às estruturas dúcteis-rúpteis. Contudo, a distribuição dos corpos mineralizados no Prospecto Aurora (Fig. 8) é fortemente controlada pela geometria do Lineamento Patos. Assim como previsto no modelo de arranjo do

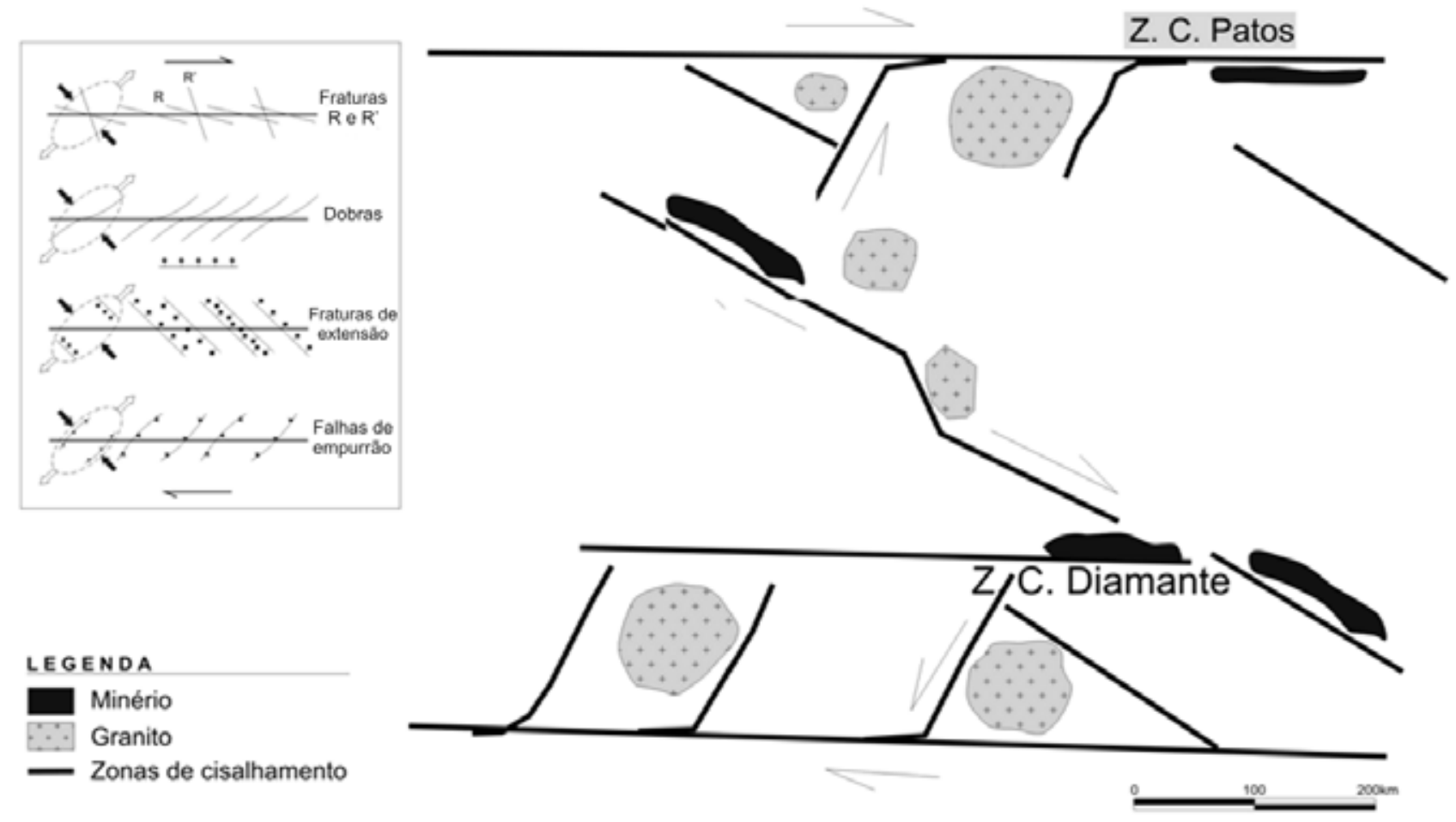

Figura 8 - Modelo estrutural regional para o posicionamento de corpos graníticos brasilianos e os corpos de minério dos Prospectos Aurora. 
tipo dominó, proposto por Jardim de Sá (1994), tais corpos associam-se às estruturas antitéticas extensionais em relação ao Lineamento Patos, de direção aproximadamente NW-SE (Fig. 8). Tais estruturas seriam relacionadas à abertura de espaços e a formação de cunhas adequadas para a circulação de fluidos hidrotermais e geração das faixas mineralizadas no Prospecto Aurora.

A associação espacial entre brechas hidrotermais mineralizadas e o desenvolvimento de estruturas antitéticas associadas ao desenvolvimento de zonas de cisalhamento dúcteis ou dúcteis-rúpteis têm sido descritas para outros depósitos do tipo IOCG, como aqueles da Província Mineral de Carajás (Nelson et al. 2007). Nesses depósitos são reconhecidos estágios de alteração de mais alta temperatura, tais como alteração sódica ou sódico-cálcica, associados a estruturas miloníticas que teriam sido formadas em fases intersísmicas e acompanhadas pelo aumento da pressão de fluidos. O estágio de mineralização com formação das associações com sulfetos, contudo, teria ocorrido durante fases sísmicas com liberação da alta pressão de fluidos, o que seria acompanhado por brechação (Nelson et al. 2007).

Enquanto a associação espacial com o Lineamento Patos sugere idade neoproterozoica (orogênese brasiliana) para a ocorrência cuprífera do Prospecto Aurora, a presença de mineralização também encaixada na Bacia eopaleozoica de Iara, a exemplo das mineralizações conhecidas nas Bacias do Cococi, São Julião e Jaibaras (Parente \& Arthaud 2004), indica que o evento mineralizante pode ter sido recorrente ou condicionado por reativações tardi a pós-brasilianas.

Com relação à origem da mineralização cuprífera do Prospecto Aurora, a participação de componentes oriundos de fluidos magmáticos, associados à colocação de batólitos graníticos brasilianos ou tardibrasilianos pode ser facilmente aventada. No entanto, assim como em outros depósitos IOCG reconhecidos em importantes províncias metalogenéticas, tal como Carajás, não há uma ligação direta entre o posicionamento destes batólitos e a mineralização aqui investigada.

Com base na íntima associação com sistemas hidrotermais potássicos, assim como à presença de hematita em zonas brechadas, é plausível postular que o Prospecto Aurora representa um análogo Neoproterozoico a Eopaleozoico dos sistemas IOCG. Essa constatação revela enormemente o potencial metalogenético para cobre na Província Borborema, principalmente ao longo de grandes descontinuidades crustais.
CONCLUSÕES As principais conclusões obtidas a partir do estudo do prospecto Aurora são listadas abaixo e, globalmente, indicam potencialidade para pesquisa de depósitos de cobre de valor econômico na Província Borborema:

1) No contexto regional, a zona mineralizada posiciona-se em uma zona de cisalhamento secundária ao Lineamanto Patos - principal descontinuidade estrutural regional;

2) No contexto local, a mineralização está condicionada a zonas de brechação tardias. Os corpos mineralizados são controlados estruturalmente e posicionados segundo a lineação de estiramento;

3) As ocorrências de cobre reportadas no Prospecto Aurora relacionam-se aos processos epigenéticos, cujos produtos recortam unidades geológicas de diferentes idades;

4) Os processos de alteração hidrotermal incluem cloritização e albitização associados às zonas de cisalhamento dúcteis secundárias à zona de cisalhamento transcorrente sinistral compreendida no Lineamento Patos, que são superpostas por zonas de brechação com potassificação e hematitização tardias. A sufetação (pirita e calcopirita) relaciona-se intimamente com esta fase tardia;

5) A exemplo do que ocorre em outros depósitos IOCG mundiais, não há um relacionamento genético direto entre o posicionamento de batólitos graníticos brasilianos e a mineralização no Prospecto Aurora;

6) As principais características do Prospecto Aurora, tais como controle estrutural, associação com brechas hidrotermais ricas em óxidos de ferro, tipos e sequência de estágios de alteração hidrotermal, permitem classificá-lo como representante de um depósito IOCG. A formação do depósito pode estar relacionada a uma possível ligação entre os fluidos hidrotermais e batólitos graníticos brasilianos a tardibrasilianos.

Esse estudo indica perspectiva para pesquisa de depósitos IOCG de classe mundial na Província Borborema, vinculados ao evento Brasiliano e às possíveis reativações mais recentes.

Agradecimentos À VALE pela cessão dos dados e pelo apoio concedido durante a execução desta pesquisa. Em especial, aos colegas da equipe de exploração mineral, cuja ajuda e incentivo foram essenciais para execução e conclusão deste trabalho. Agradecimentos também são devidos aos revisores anônimos da RBG pelos úteis comentários que contribuíram para a melhora desse manuscrito.

\section{Referências}

Almeida F.F.M., Hasui Y., Brito-Neves B.B. 1976. The Upper Precambrian of South America. Boletim $I G$, 7:45-80.

Almeida F.F.M., Hasui Y., Brito-Neves B.B., Fuck R. 1977. Províncias estruturais brasileiras. In: SBG, Simpósio Geologia do Nordeste, 8, Resumos, p. 363-391.
Barbosa O. 1970. Geologia econômica de parte da região do médio São Francisco. Nordeste do Brasil. Rio de Janeiro, DNPM/DFPM, Boletim 140, 97 p.

Bittar S.M.B. 1998. Faixa Piancó-Alto Brígida: terreno tectono-estrutural sob regimes metamórficos e deformacionais contrastantes. Tese de Doutorado, 
Instituto de Geociências, Universidade de São Paulo, São Paulo, 126 p.

Brito-Neves B.B. 1975. Regionalização geotectônica do Precambriano nordestino. Tese de Doutorado, Instituto de Geociências, Universidade de São Paulo, São Paulo, $198 \mathrm{p}$.

Brito-Neves B.B. 1983. O mapa geológico do nordeste Oriental do Brasil escala 1:1.000.000. Tese de Livre Docência, Instituto de Geociências, Universidade de São Paulo, São Paulo, 177 p.

Brito-Neves B.B., Santos E.J., Van Somos W.R. 2000. Tectonic History of the Borborema Province. In: Cordani U.G., Milani E.J., Thomaz Filho A., Campos D.A. (ed.) Tectonic evolution of South America. Rio de Janeiro, FINEP, p.151-182.

Brito-Neves B.B., Van Schmus W.R., Kozuch M., Santos E.J. dos, Petronilho L. 2005. A Zona Tectônica Teixeira Terra Nova - ZTTTN - Fundamentos da Geologia Regional e Isotópica. Geologia USP. Série Científica, 5(1):57-80.

Campos Neto M.C., Bittar S.M.B., Brito-Neves B.B. 1994. Domínio tectônico Rio Pajeú-Província Borborema: orogêneses superpostas no Ciclo Brasiliano/Panafricano. In: SBG, Cong. Bras. Geol., 38, Anais, p. 221-222.

Cox D.P., Singer, D.A., Barton Jr., P.B., 1986. Mineral deposit models. U.S. Geological Survey Bulletin, 1693:1-10.

CPRM 1982. Projeto Aurora. Fortaleza, SUREG FO, Relatório Técnico, 48 p.

Ferreira C.A. \& Santos E.J. 2000. Programa de Levantamentos Geológicos Básicos do Brasil. Jaguaribe SE, Folha SC.24-Z. Brasília, CPRM, mapa geológico, escala 1:500.000. 1 CD-Rom.

Gomes H.A. 1998. Programa de Levantamentos Geológicos Básicos do Brasil. Serra Talhada, Folha SC.24-Z-C. Brasília, CPRM, mapa geológico, escala 1:250.000. 1 CD-Rom.

Grainger C.J., Groves, D.I., Tallarico, F.H.B., and Fletcher, I.R., 2008, Metallogenesis of the Carajás mineral province, southern Amazon craton, Brazil: Varying styles of Archean through Paleoproterozoic to Neoproterozoic base-and precious-metal mineralisation. Ore Geology Reviews, 33:451-489.

Groves D.I., Bierlien F.K., Menert L.D. Hitzman M.W. 2010. Iron Oxide Copper-Gold (IOCG) Deposits through Earth History: Implications for Origin, Lithospheric Setting and Distribition from Other Epigenetic Iron Oxide Deposit. Economic Geology, 105(3):641-654.

Hitzman M.W., Oreskes N., Einaudi M.T. 1992. Geological characteristics and tectonic setting of Proterozoic iron oxide (Cu-U-Au-REE) deposits. Precamb. Res., 58:241-287.

Huhn S.R.B. \& Nascimento J.A.S. 1997. São os depósitos cupríferos de Carajás do Tipo $\mathrm{Cu}-\mathrm{Au}-\mathrm{U}-\mathrm{ETR}$ ? In: Costa M.L., Angélica R.S. (coords.) Contribuições a Geologia da Amazônia. Belém, FINEP/SBG-NO, p. 143-160.

Jardim de Sá E.F. 1994. A Faixa Seridó (Província Borborema, NE do Brasil) e o seu significado geodinâmico na Cadeia Brasiliana/Pan-Africana. Tese de Doutorado, Instituto de Geociências, Universidade de Brasília, Brasília, 803 p.
Jardim de Sá E.F., Macedo M.H.F., Fuck R.A. 1992. Terrenos Proterozóicos na Província Borborema e a margem norte do Cráton São Francisco. Rev. Bras. Geoc., 22:472-480.

Justo A.P., Veira L., Leão M.H., Sena F., Meneguessso, G. 2008. Projeto Cobre Brasil Aurora. Fortaleza, DIPM/ GEGEK, Relatório de Etapa, 63 p.

Kozuch M, Bittar S.M., Van Schmus W.R. 1997. Late Proterozoic and Middle Neoproterozoic magmatism in the Zona Transversal of Borborema Province, Brasil. In: SBG, Simpósio de Geologia do Nordeste, 17, Resumos Expandidos, p. 47-50.

Maas M.V.R., Oliveira C.G., Pires A.C.B., Moraes R.A.V. 2003. Aplicação da Geofísica Aérea na Exploração Mineral e Mapeamento Geológico do Setor Sudoeste do Cinturão Cuprífero Orós-Jaguaribe. Rev. Bras. Geoc, 33(3):279-288.

Machado M.A. 2006. Caracterização Descritiva e Genética de Ocorrências Cupro- Hematíticas no Setor Sudoeste do Sistema Orós-Jaguaribe Província Borborema. Dissertação de Mestrado, Instituto de Geociências, Universidade de Brasília, Brasília, 102 p.

Monteiro L.V.S., Xavier R.P., Carvalho E.R., Hitzman M.W., Johnson C.A., Souza Filho C.R., Torresi I. 2008. Spatial and temporal zoning of hydrothermal alteration and mineralization in the Sossego iron oxide-copper-gold deposit, Carajás Mineral Province, Brazil: Paragenesis and stable isotope constraints. Mineralium Deposita, 43:129-159.

Nelson E.P., Hitzman M.W., Monteiro L.V.S. 2007. Hydrothermal metamorphism and transient depth fluctuations of the brittle-ductile transition during shearzone hosted IOCG mineralization. Geological Society of America Abstracts with Programs, 39(6):535.

Oliveira R.G., Santos E.J., Medeiros V.C. 2000. Magnetic and Gamma-ray Spectometry signatures from terranes, Lineaments and Granitoids Rocks Belonging to The Proterozoic Structural Borborema Province, Northeast Brazil. In: General Symposia, International Geological Congress, 31, Poster Session. 1 CD-Rom.

Oliveira R.G. 2008. Arcabouço Geofísico, Isostasia e Causas do Magmatismo Cenozóico da Província Borborema e de Sua Margem Continental (Nordeste do Brasil). Tese de Doutorado, Centro de Ciências Exatas e da Terra, Universidade Federal do Rio Grande do Norte, Natal, 411 p.

Parente C.V. \& Arthaud M.H. 1995. O Sistema OrósJaguaribe no Ceará, NE do Brasil. Rev. Bras. de Geol., 25(4):297-306.

Parente C.V. \& Arthaud M.H. 2004. Geologia e tipologia do minério da ocorrência de $\mathrm{Cu}-\mathrm{Fe}$ associada à Seqüência Metavulcano-sedimentar Cachoeirinha, região de Aurora - CE. Rev. Geol. da UFC, 17(2):157-172.

Pollard P.J. 2000. Evidence of a magmatic fluid and metal source for Fe-oxide $\mathrm{Cu}-\mathrm{Au}$ mineralisation. In: Porter T.M. (ed.) Hydrothermal iron oxide copper-gold and related deposits: A global perspective. Australian Mineral Foundation. Adelaide, Porter GeoConsultancy Pty Ltd., p. 27-41. 
Pollard P. 2006. An Intrusion-related origin for $\mathrm{Cu}-$ $\mathrm{Au}$ mineralization in iron oxide-copper-gold IOGC provinces. Mineralium Deposita, 41:179-187.

Santos EJ. 1996. Ensaio preliminar sobre terrenos e tectônica acrescionária na Província Borborema. In: SBG, Congresso Brasileiro de Geologia, 39, Anais, p. 47-50.

Santos E.J., Oliveira R.G., Paiva I.P. 1997. Terrenos do Domínio Transversal da Província Borborema: controles sobre acresção e retrabalhamento crustais ao sul do Lineamento Patos. In: SBG, Simpósio de Geologia do Nordeste, 17, Resumos Expandidos, p. 11-14.

Santos E.J. 1999. Programa de Levantamentos Geológicos Básicos do Brasil: carta geológica. Belém do São Francisco, Folha SC.24-X-A. Brasília, CPRM, mapa geológico, escala 1:250.000. 1 CD-Rom.

Santos E.J. \& Brito-Neves B.B. 1984. Província Borborema. In: Almeida F.F.M., Hasui Y. (eds.) O Pré-Cambriano do Brasil. São Paulo, Edgard Blucher, p. 123-186.

Santos E.J., Coutinho M.G.N., Costa M.P.A., Ramalho R. 1984. A região de dobramentos Nordeste e a Bacia do Parnaíba, incluindo o Cráton São Luís e as bacias marginais. In: Schobbenhaus C., Campos D.A., Derze G.R., Asmus H.E. (eds.) Geologia do Brasil. Brasília, DNPM, p. 131-198.

Silva Filho M.A., Nesi J.R., Mendes V.A. 1985. Projeto Cachoeirinha. Recife, DNPM/CPRM, Relatório final integrado, $128 \mathrm{p}$.
Van Schmus W.R., Brito-Neves B.B, Hackspacher P., Babinski M. 1995. U/Pb and $\mathrm{Sm} / \mathrm{Nd}$ geochronologic studies of the Eastern Borborema Province, NE of Brazil: initial conclusions. Journal of South American Earth Sciences, 8:267-288.

Ward J.H. 1963. Hierarquical Grouping to optimize an objective function. Journal of American Statistical Association, 58(301):236-244.

Williams P.J., Barton M.B., Johnson D.A., Fontboté L., Haller A., Mark G., Oliver N.H., Marschik R. 2005. Iron oxide copper-gold deposits: geology, space-time distribution, and possible modes of origin. In: Hedenquist J.W., Thompson J.F.H., Goldfarb R.J., Richards J.P. (eds.) Economic Geology 100th Anniversary Volume. Littleton, Society of Economic Geologists, p. 371-405.

Xavier R.P., Wiedenbeck M., Trumbull R.B., Dreher A.M., Monteiro L.V.S., Rhede D., Araújo C.E.G., Torresi I. 2008. Tourmaline B-isotopes fingerprint marine evaporates as the source of high-salinity ore fluids in iron oxide-copper-gold deposits, Carajás Mineral Province (Brazil). Geology, 36:743-746.

Manuscrito ID 20495

Submetido em 07 de janeiro de 2011 Aceito em 13 de outubro de 2011 